\title{
Upaya Meningkatkan Aktivitas dan Hasil Belajar Bahasa Indonesia Melalui Model Pembelajaran Group Investigation dengan Pendekatan Galery
}

\author{
I Gusti Agung Made Gede Mudana* \\ Jurusan Dharma Acarya,Program Studi Sastra dan Pendidikan Bahasa Bali, STAHN Mpu Kuturan
}

\begin{tabular}{l} 
A R T I C L E I N F O \\
\hline Article history: \\
\hline Received 17 February \\
2019 \\
Received in revised form \\
27 March 2019 \\
Accepted 18 April 2019 \\
Available online 28 May \\
2019 \\
\hline Kata Kunci: \\
Pembelajaran Kooperatif \\
tipe Group Investigation \\
(GI), Aktivitas dan Hasil \\
Belajar \\
Keywords: \\
Inquiry, concrete media, \\
learning outcomes, \\
Mathematics
\end{tabular}

\begin{abstract}
A B S T R A K
Penelitian ini dilaksanakan di kelas X.9 SMAN 8 Denpasar dengan tujuan untuk meningkatkan aktivitas dan hasil belajar bahasa Indonesia dengan menggunakan metode pembelajaran Group Investigation melalui pendekatan galery. Menurut Slavin (1995) pembelajaran Group Investigation (GI) adalah pembelajaran yang dilakukan secara berkelompok, siswa dalam satu kelas dijadikan kelompok-kelompok kecil yang terdiri dari 4 sampai 5 orang untuk memahami konsep yang difasilitasi oleh guru. Galery adalah segala sesuatu yang diwujudkan secara visual yang diwujudkan dalam bentuk dua dimensi sebagai curahan perasaan atau fikiran (Hamalik, 1986). Jadi Galery yang dimaksud disini adalah hasil kerja kelompok yang dipajang secara visual dan kelompok lain memberikan input atau pendapat mengenai hasil karya kelompok. Penelitian ini dirancang dalam dua siklus dengan masing-masing siklus terdiri atas tahap perencanaan, pelaksanaan, observasi, evaluasi serta analisis dan refleksi tindakan. Dalam penelitian ini diperoleh informasi bahwa aktivitas belajar siswa tergolong cukup aktif pada siklus I, menjadi tergolong sangat aktif pada siklus II. Hasil belajar siswa tergolong tuntas yaitu dari 68,02 pada siklus I, menjadi 83,02 pada siklus II. Diharapkan kedepan, model pembelajaran ini bisa diterapkan dalam proses pembelajaran pada mata pelajaran yang lain sehingga apa yang menjadi tujuan pendidik yaitu meningkatkan kualitas pendidikan tercapai.
\end{abstract}

A B S T R A C T

This research was conducted in class X.9 of SMAN 8 Denpasar with the aim of increasing the activity and learning outcomes of Indonesian language by using the Group Investigation learning method through a gallery approach. According to Slavin (1995) learning Group Investigation (GI) is learning carried out in groups, students in one class are made into small groups of 4 to 5 people to understand the concepts facilitated by the teacher. The gallery is everything that is manifested visually which is manifested in a two-dimensional form as an outpouring of feelings or thoughts (Hamalik, 1986). So the gallery that is meant here is the result of group work that is displayed visually and other groups provide input or opinions regarding the group's work. This research was designed in two cycles with each cycle consisting of the stages of planning, implementation, observation, evaluation and analysis and reflection of action. In this study obtained information that student learning activities are quite active in the first cycle, being classified as very active in the second cycle. Student learning outcomes are classified as complete, namely from 68.02 in the first cycle, to 83.02 in the second cycle. It is expected that in the future, this learning model can be applied in the learning process in other subjects so that what is the goal of educators is to improve the quality of education achieved. 


\section{Pendahuluan}

Berbagai strategi dan pendekatan pembelajaran telah banyak dikembangkan dalam meningkatkan aktivitas dan keterlibatan siswa dalam proses pembelajaran. Akan tetapi kenyataannya di lapangan, hasil belajar siswa SMA yang diterima di SMA N 8 Denpasar khususnya mata pelajaran Bahasa Indonesia belum menggembirakan dalam arti rata-rata nilai ujian sekolah untuk mata pelajaran Bahasa Indonesia belum memenuhi standar KKM yang ditetapkan di SMAN 8 Denpasar sebesar 70.

Rendahnya hasil belajar siswa pada mata pelajaran Bahasa Indonesia disebabkan oleh: (1) Pembelajaran Bahasa Indonesia yang dilakukan selama ini tidak memperhatikan konsepsi atau pengetahuan awal yang dimiliki siswa. (2) Penyajian materi pelajaran Bahasa Indonesia di sekolah, tampaknya masih semata-mata berorientasi kepada yang tercantum pada kurikulum dan buku teks. (3) Bagi para siswa pelajaran Bahasa Indonesia tampaknya hanya untuk menghadapi ulangan atau ujian, dan terlepas dari permasalahan-permasalahan dari kehidupan sehari-hari. (4) Aktivitas siswa dalam mengikuti pelajaran Bahasa Indonesia masih kurang yang ditandai dengan masih kurangnya aktivitas siswa dalam menjawab pertanyaan yang dikemukakan oleh guru.

Salah satu upaya untuk memperbaiki adalah dengan penerapan pendekatan kontekstual, di sisi lain perlu diimbangi dengan setting pembelajaran yang memberikan kesempatan kepada siswa untuk mengembangkan pola fikirnya secara optimal. Setting pembelajaran yang cocok untuk menerapkan pendekatan kontekstual guna mengetahui perkembangan dan kemajuan siswa adalah setting cooperative learning tipe group investigation (GI).

Model pembelajaran Bahasa Indonesia tipe group investigation (GI) memungkinkan guru dapat menerapkan penilaian untuk mengetahui kompetensi pemahaman konsep dan aktivitas siswa, karena dalam pembelajaran dengan group investigation (GI) ini, siswa yang berperan aktif dalam proses pembelajaran.

Group Investigation (GI). Dengan teori ini, peneliti bisa melakukan pemeriksaan atau investigasi secara berkelompok. Proses kerja teori ini adalah guru membagi kelas menjadi kelompok-kelompok dengan anggota 5-6 orang yang heterogen (Sujaya, 2005).

Dalam melakukan penyelidikan siswa dituntut memiliki keterampilan proses sains. Keterampilan proses sains merupakan proses belajar yang dapat membantu siswa memperluas pengetahuan melalui pengalaman langsung, sehingga siswa mampu menemukan dan mengembangkan sendiri fakta dan konsep yang sedang dipelajari (Sujaya, 2005). Keterampilan proses yang dimaksud yaitu keterampilan mengamati, menafsirkan pengamatan, meramalkan, menggunakan alat dan bahan, menerapkan konsep, merencanakan penelitian, dan mengajukan pertanyaan (Wirta, 1999).

Menurut Slavin (dalam Mahendra, 2003) tahapan-tahapan dalam menerapkan pendekatan pembelajaran kooperatif tipe group investigation adalah sebagai berikut. (1) Tahap Grouping (pemilihan topik) . (2) Tahap Planning (perencanaan kooperatif), (3) Tahap Investigation/Implementasi, (4) Tahap Organizing/Sintesis dan Analisis, (5) Tahap Presentating (presentasi), (6) Tahap Evaluating (evaluasi).

Galery adalah segala sesuatu yang diwujudkan secara visual yang diwujudkan dalam bentuk dua dimensi sebagai curahan perasaan atau fikiran (Hamalik, 1986). Jadi Galery yang dimaksud di sini adalah hasil kerja kelompok yang dipajang secara visual dan kelompok lain memberikan input atau pendapat mengenai hasil karya kelompok.

\section{Metode}

Penelitian ini tergolong penelitian tindakan kelas (classroom action reseach) yang secara umum bertujuan untuk meningkatkan kualitas pembelajaran di sekolah pada umumnya dan di dalam kelas pada khususnya yang bermuara pada peningkatan kompetensi dasar siswa. Penelitian ini dilaksanakan pada suatu kelas yang mempunyai permasalahan. Tindakan yang dilakukan dalam penelitian ini adalah model pembelajaran kooperatif tipe group investigation (GI).

Subjek penelitian ini adalah siswa kelas X.9 Semester II SMA N 8 Denpasar yang berjumlah 48 orang terdiri dari 22 orang laki-laki dan 26 orang perempuan. Secara umum rata-rata nilai rata-rata tes awal mata pelajaran Bahasa Indonesia di SMA masih di bawah kategori ketuntasan minimal (KKM). Karena itu, walaupun kelas X.9 tuntas (sesuai dengan KKM sekolah), perlu adanya pengkajian lebih mengingat kelas X.9 sebagai kelas unggul. Sebagai kelas unggul hendaknya memiliki nilai yang minimal sama dengan nilai yang ditetapkan (kurikulum nasional) yaitu 70\%. Objek penelitian ini adalah : 1). kompetensi dasar siswa pada aspek kognitif, dan afektif siswa, 2). respon siswa terhadap penerapan model pembelajaran kooperatif tipe group investigation (GI). 


\section{Hasil dan Pembahasan}

Penelitian ini dilaksanakan dalam dua siklus dimana masing-masing siklus terdiri dari beberapa tahapan. Prosedur penelitian tindakan kelas ini untuk masing-masing siklus mencakup beberapa tahapan yaitu: tahap perencanaan, tahapan pelaksanaan tindakan, tahapan evaluasi tindakan, dan tahap refleksi tindakan. Adapun rancangannya seperti gambar 01 berikut ini.

Jika dilihat secara klasikal ketuntasan belajar siswa kelas X.9 SMA N 8 Denpasar pada siklus I adalah 54,17\%. Hal ini menunjukkan bahwa belum mencapai kriteria keberhasilan yaitu dengan ketuntasan minimal (85\%). Rata-rata hasil belajar secara klasikal 68,02 belum mencapai hasil yang diharapkan yaitu mencapai (70-). Daya serap mencapai $(68,02 \%)$ yang berada pada kategori sedang, namun belum mencapai hasil yang diharapkan yaitu dengan daya serap minimal mencapai $(70 \%)$ untuk mencapai kategori dan nilai siswa masih sedang. Hasil belajar yang dicapai siswa masih belum optimal karena dalam penerapan metode Group Investigation (GI), siswa belum optimal karena sebelumnya guru selalu menerapkan metode ceramah.

Hal-hal yang perlu dicermati dalam penerapan model pembelajaran kooperatif tipe group investigation (GI) yang telah dilaksanakan dalam siklus I adalah mengenai proses pembelajaran yang berpengaruh pada hasil kegiatan pembelajaran. Kegiatan pembelajaran pada siklus I yang terbagi menjadi 3 kali pertemuan sudah berlangsung dengan cukup baik. Namun masih ditemukan beberapa permasalahan dalam proses pembelajaran yang masih perlu dijadikan refleksi untuk perbaikan pada siklus selanjutnya. Secara umum permasalahan yang muncul pada siklus I adalah sebagai berikut : 1) Sikap siswa pada saat pelaksanaan diskusi belum optimal hanya beberapa anggota kelompok saja yang serius aktif, sedangkan anggota kelompok yang lainnya masih diam. Hal tersebut dapat mempengaruhi anggota kelompok yang sudah aktif dan mengganggu jalannya diskusi. Cara yang digunakan peneliti untuk mengurangi hal tersebut pada pelaksanaan belajar siklus II adalah dengan melakukan bimbingan kepada siswa secara individual yang mempunyai masalah belajar, 2) Kerjasama dalam satu kelompok belum optimal. Siswa yang aktif dan pintar mendominasi jalannya diskusi saat tanya jawab, 3) Siswa yang pintar menjadi lebih dominan dalam kegiatan diskusi dan presentasi kelompok, baik dalam mengajukan pertanyaan, menanggapi atau memberikan pendapat dan sanggahan. Sementara siswa yang kemampuannya rendah hanya mendengarkan apa yang sedang terjadi saat berdiskusi, dan 4) Kesiapan siswa saat dilaksanakn tes masih kurang, terbukti banyak siswa yang menjawab soal masih melihat buku atau menunggu jawaban temannya. Perbaikan yang dilakukan pada siklus II adalah mensosialisasikan kembali kriteria penilaian yang sesungguhnya seperti pada petunjuk soal, dan strategi menjawab soal benar.

Dari tes akhir siklus II, menunjukkan bahwa siswa yang belum tuntas dalam kopetensi dasar tersebut berkurang yaitu dari 22 orang pada siklus I (dengan peserta tes 48 orang) menjadi semua siswa tuntas. Dengan kata lain, siswa yang tuntas pada siklus II berjumlah 48 orang dengan perolehan nilai tertinggi sebesar 90 dan terendah 75. Secara lengkap hasil tes siswa siklus II

Tabel 1. Ringkasan Analisis Data Tes Awal dengan Tes Akhir Siklus I-II

\begin{tabular}{ccccc}
\hline NO & ASPEK & TES AWAL & SIKLUS I & SIKLUS II \\
\hline 1 & $\mathrm{~N}$ & & 48 & \\
2 & $\sum \mathrm{X}$ & 2770 & 3265 & 3985 \\
3 & Rata-rata Kelas & 57.71 & 68.02 & 83.02 \\
4 & Daya Serap (\%) & $57.71 \%$ & $68.02 \%$ & $83.02 \%$ \\
5 & Ketuntasan (\%) & $8.33 \%$ & $54.17 \%$ & $100 \%$ \\
\hline
\end{tabular}

Berdasarkan ringkasan analisis data tes awal sampai dengan tes akhir baik itu pada siklus I dan siklus II seperti tercantum pada tabel di atas menunjukkan peningkatan rata-rata kelas, daya serap siswa, dan ketuntasan pada akhir siklus II sudah melebihi kriteria minimal 85\%. Dengan begitu hipotesis yang diajukan dalam penelitian ini dapat diterima dan berarti, metode pembelajaran Group Investigation (GI) dengan pendekatan galery untuk meningkatkan aktifitas dan hasil belajar Bahasa Indonesia pada siswa kelas X.9 Semester II SMA N 8 Denpasar.

\section{Simpulan Dan Saran}

Hasil pembahasan yang telah diuraikan di atas, dapat disimpulkan bahwa Penerapan model pembelajaran kooperatif tipe group investigation (GI) dengan pendekatan galery dapat meningkatkan kompetensi pemahaman konsep siswa kelas X.9 semester II SMA N 8 Denpasar. Hal ini dapat terlihat dari 
nilai rata-rata pada tiap pertemuan siklus I sebesar 68,02 dengan ketuntasan klasikal $54,71 \%$ dan pada siklus II meningkat menjadi 83,02 dengan ketuntasan klasikal 100\%.

Berdasarkan simpulan di atas, dapat disampaikan beberapa saran yaitu: 1. Bagi guru, dalam menerapkan model pembelajaran berbantuan media konkret pada proses pembelajaran dikelas perlu memahami langkah-langkah model pembelajaran inkuiri, serta memperhatikan: (a) Alokasi waktu diatur sebaik mungkin sehingga tiap tahapan pembelajaran dapat berlangsung secara optimal; (b) Pembagian kelompok harus benar-benar diperhatikan yakni secara heterogen berdasarkan jenis kelamin dan prestasi siswa; (c) Memberikan bimbingan individu dan kelompok secara merata; (d) Memahami sifat dan karakteristik anak, 2. Bagi siswa, siswa diharapkan berperan aktif dalam pembelajaran, memperhatikan penjelasan guru dan ikut terlibat dalam setiap kegiatan pembelajaran sehingga prestasi belajar akan meningkat serta diharapkan dapat berkerja secara mandiri maupun kelompok dan bertanggungjawab atas tugas yang diberikandan 3. Bagi Kepala Sekolah, diharapkan mengembangkan dan mengkaji lebih luas lagi model-model pembelajaran untuk mendukung proses belajar mengajar yang sesuai dengan kurikulum dan karakteristik anak meliputi sarana dan prasarana yang menunjang pembelajaran

\section{Daftar Rujukan}

Azizah, Ulfah. "Peningkatan Hasil Belajar Mata Pelajaran Ipa Di Kelas Ii Dengan Menggunakan Strategi Card Sort Di Mi Ma'arif Nu Cipete Kecamatan Cilongok Kabupaten Banyumas Tahun Pelajaran 2015/2016."

Faujiah, Chera Rizqi, Idad Suhada, and Sri Hartati "PENERAPAN MODEL PEMBELAJARAN GROUP INVESTIGATION TEHADAP HASIL BELAJAR SISWA PADA MATERI SISTEM EKSKRESI MASNUSIA." Jurnal BIOEDUIN: Program Studi Pendidikan Biologi 7.1 (2017): 64-75

Herlina, Anita. "Pengaruh Model GI-GI (Group Investigation-Guided Inquiry) Tehadap Kemampuan MultiRepresentasi dan Aktivitas Belajar Siswa Dalam Pembelajaran Fisika (pada Materi Suhu dan Kalori) di SMA Jember." (2016)

Jayadiningrat, Made Gautama, I. Nyoman Tika, and Ni Putu Yuliani. "Meningkatkan Kesiapan Dan Hasil Belajar Siswa Pada Pembelajaran Kimia Dengan Pemberian Kuis Di Awal Pembelajaran." Jurnal Pendidikan Kimia Indonesia 1.1 (2017): 7-12.

Lestari, Fuji. Pengaruh Model Pembelajaran Berbasis Masalah dengan Teknik Gallery Walk terhadap Kemampuan Berpikir Kritis Matematis Siswa. BS thesis. Jakarta: FITK UIN Syarif Hidayatullah Jakarta, 2018

Maghfuranh, Akhmad. Efektivitas metode inquiry terhadap hasil belajar materi pencemaran dan kerusakan lingkungan kelas VII MTS Taqwal Ilah Meteseh Tembalang Semarang. Diss. IAIN Walisongo, 2014.

Mahendra. 2003. Pembelajaran kontekstual dan implementasi kurikulum berbasis kompetensi. Makalah, disajikan pada Seminar Jurusan Pendidikan Fisika IKIP.

Nur, Ahmad Tajuddin. "MODEL PEMBELAJARAN GI-GI ( GROUP INVESTIGATION GUIDED INQUIRY) DALAM PEMBELAJARAN FLUIDA DINAMIS DI SMA (STUDY PADA KETERAMPILAN PROSES SAINS DAN HASIL BELAJAR SISWA)". (2016).

Oktavianto, Dwi Angga, and Budi Handoyo Sumarmi. "PENGARUH PEMBELAJARAN BERBASIS PROYEK BERBANTUAN GOOGLE EARTH TERHADAP KETERAMPILAN BERPIKIR SPASIAL." Jurnal Teknodik 21.1 (2017): 059

Prasetyo, Budi. "Efektivitas Pendekatan Saintifik Dalam Meningkatkan Motivasi Belajar Siswa Kelas Vii Pada Mata Pelajaran Sejarah Kebudayaan Islam (Ski) Di Madrasah Tsanawiyah (Mts) Negeri Tumpang." 
Setiawan, Roni. Pengaruh Model Pembelajaran Kooperatif Tipe Gallery Walk Pada Pelajaran Ekonomi Kelas X DI SMA Negeri 5 Tellu Limpoe. Diss. Ekonomi, 2018.

Siswaya, Ida Bagus Widana. "The Implementation of the NHT Type of Cooperative Learning Model to Improve Student's Activities and Learning Achievement in Basic Techniques for Passing Inner Legs." Journal of Education Action Research 3.1 (2019): 1-8.

Sujaya, I M. 2005. Penerapan pendekatan kontekstual dengan setting kooperatif tipe group investigation (GI) sebagai upaya meningkatkan kompetensi dasar dalam pembelajaran energi dan usaha pada siswa kelas IA2 SMP Negeri 1 Singaraja. Skripsi (tidak diterbitkan). Jurusan Pendidikan Fisika. Fakultas Pendidikan MIPA IKIP N Singaraja

Sujana, N. 1991. Penilaian Hasil Proses Belajar. Bandung: PT Remaja Rosdakarya.

Sukelasmini, I. Gusti Ayu Made. "The Implementation of Think Pair Share (TPS) Type of Cooperative Learning Model To Improve Student's Motivation And Nutrition Science Learning Achievement." Journal of Education Action Research 3.1 (2019): 9-15.

Sumardi, S. "Pembelajaran Matematika dengan Student Team Achievement Division dan Numbered Head Together terhadap Hasil Belajar Ditinjau dari Kemampuan Awal Siswa SMP." Manajemen Pendidikan 12.3 (2017): 179-190.

Tahir, Sitti Fatimah. "Perbandingan Pemahaman Konsep Matematika Menggunakan Model Pembelajaran Problem Based Learning Dan Model Pembelajaran Group Investigation Pada Siswa Kelas Xi Ipa Man 1 Makassar."

Tambunan, Elida, and Nurdin Bukit. "Analisis Pengaruh Model Pembelajaran Kooperatif Tipe Group Investigation dan Pemahan Konsep awal Terhadap hasil Belajar siswa Di SMA Negeri 1 Teluk Mengkudu." Jurnal Pendidikan Fisika 4.1 (2015): 49-56.

Wati, Novika Rahma. "Penerapan Model The Power Of Two Untuk Meningkatkan Hasil Belajar IPS Siswa Kelas IV B SD Negeri 2 Rukti Harjo." (2016).

Wirta. 1999. Teori-teori Belajar. Jakarta: Erlangga 